\title{
The Rockefellers to the rescue
}

\author{
Rockefeller Foundation funding and \\ medical education in Toronto, Montreal, \\ and Halifax \\ Marianne P. Fedunkiw \\ Montreal and Kingston: McGill-Queen's \\ University Press; 2005 \\ 201 pp \$75 (cloth) ISBN o-7735-2897-0
}

$\mathrm{B}$ etween I920 and I935 the Rockefeller Foundation gave Canadian medical schools more than $\$ 5$ million to modernize their teaching programs, construct new buildings for medical sciences and hire more full-time hospital and academic teaching staff - sweeping measures that changed the face of medical education in Canada. By scrupulous examination of archival sources, Marianne Fedunkiw has reconstructed this surprisingly neglected phase of Canadian medical history.

Explaining this magnanimous gift, John D. Rockefeller on I8 December, I9I9, wrote to the Board of the Rockefeller Foundation "My attention has been called to the needs of some of the medical schools in Canada... The Canadian people are our near neighbours. They are closely bound to us by ties of race, language and international friendship; and they have without stint sacrificed themselves their youth and their resources to the end that democracy might be saved and extended. For these reasons if your Board should see fit to use any part of this new gift in promoting medical education in Canada, such action would meet with my cordial approval." With this warm testimonial, Rockefeller turned over $\$ 50$ million to the Rockefeller Foundation, which had as its mandate "the well-being of mankind": its Board set aside $\$ 5$ million for Canadian medical schools.

Although Fedunkiw does not emphasize it, the origin of this Rockefeller gift can be traced back to William Osler. As Harvey Cushing pointed out in his Life of Sir William Osler (Oxford University Press, I925), Osler's The Principles and Practice of Medicine was read in 1897 by Frederick Gates, then the close business confidant of John D. Rockefeller. This fired up Gates to convince Rockefeller to direct his vast fortune into medical research. The upshot was the establishment of the Rockefeller Institute for Medical Research in New York in I9or, followed by the formation in 1904 of the General Educational Board (GEB) to deal with the consolidated health programs and projects in the United States for which Rockefeller money was assigned.

An early example of Osler's relation with the Rockefellers was his successful request for $\$ 500$ ooo for Johns Hopkins Hospital to replace the revenueearning property lost in the fire of 1904 in Baltimore. It was the first of the Rockefeller donations to Hopkins that over the next 2 decades would exceed \$20 million.
Acting Principal of McGill, Frank Adams, also wrote the Rockefellers, father and son, referring to Osler's request. He did this on the advice of William Lyon McKenzie King, who had been a close advisor to the Rockefellers, having extricated them from difficult labour disasters. King himself made a strong plea to the Rockefellers indicating how valuable their support for Canadian medical education would be regarded. Foundation President George Vincent announced the $\$ 5$ million donation on the 25 December, I9I9 alas too late for Osler, who was in the last throes of a fatal lung infection.

The Rockefeller pledges had strings attached. First, the officers of the Foundation, particularly the President Vincent and Dr. Richard Pearce, Director of the Division of Medical Education, made 4 visits in the spring of 1920 to

\section{My attention has been called to the needs of ... medical schools in Canada}

Osler's next request, to replace buildings at McGill damaged by fire in 1907 (by this time he was Regius Professor at Oxford), received a warm No from Rockefeller's son, who explained that the GEB by its charter could not distribute funds outside the United States. But Osler's letter generated discussions that eventually led to the establishment of the Rockefeller Foundation in 1913 with no geographical limits to its mandate.

On 28 August, I9I9, Osler sent a handwritten note to John D. Rockefeller Jr., by way of William Welch, to request again help for McGill's Medical School and its teaching hospitals. He had already circulated a substantial outline on how McGill should augment its clinical teaching staff with joint university-hospital committees to carry out policies in medical education. His outline had been accepted with little change by McGill's Medical Faculty.

Osler's note started a chain reaction.
Canadian medical schools, after receiving their surveys. Meeting with all the important players in each of the medical schools, they thoroughly examined how the schools were operated, financed, staffed, housed and equipped. Second, the Foundation pledges were conditional on the universities generating matching funds from their alumni, local government and private donors.

Fedunkiw compares and contrasts the impact of the Rockefeller funding on each medical school at Toronto, McGill and Dalhousie. She might have enhanced her account by more cameos of the many colourful players such as the diligent officers of the Rockefeller Foundation and the Presidents, Principals and Deans of the 3 medical schools who worked so closely with them.

She recounts how the University of Toronto's vigorous President, Sir Robert Falconer, on the strength of an Eaton family endowment of $\$ 500000$ in January 1919, had appointed Duncan 
Graham as the first full-time Professor of Medicine in the Commonwealth, with authority to hire and fire medical staff. This move stirred up a protracted public commission of inquiry with regard to so-called full-time appointments and the influence of private donors on medical school policy. But after a period of "agitation and discord" the reorganization of the Toronto hospitals resulted in more effective postgraduate training, emphasis on laboratory research coupled with clinical practice and "for the first time in Canada, fair remuneration in the form of salaries paid to full-time, university-based junior researchers in internal medicine."

McGill and Dalhousie, like Toronto, had organized military hospitals that served overseas, staffed by members of the faculty and alumni. At Dalhousie, President Stanley MacKenzie pointed to the wartime devastation from the Halifax explosion, the takeover of medical education buildings for a military hospital and the absence of half of the teaching staff overseas. Thus, all 3 universities presented ample evidence to support Rockefeller's statement that "they have without stint sacrificed themselves, their youth and their resources to the end that democracy might be saved and extended."

Dalhousie received special consideration from the Rockefeller officials; to their credit they viewed the medical school in its context as the only one in the Maritimes. Flexner had almost written it off, but the Foundation officers were more flexible, concerned about the overall upgrading of the school than with the formation of a researchoriented full-time medical faculty.

General Sir Arthur Currie, perhaps the most brilliant military strategist of World War I, became Principal of McGill in May I920. He launched at once a successful centennial campaign to bolster McGill's finances; when the Rockefeller Foundation offered its pledge, Currie had matching funds already in hand so that the program was at once put into action. The rapport between the Rockefeller officers and McGill was most fruitful. Within 3 years, the university completed a biology building for medical sciences, and a pathological institute. Rockefeller funds established McGill's first fulltime professor of medicine, Jonathan Meakins (attracted back from Edinburgh), and university clinic, also headed by Jonathan Meakins, in I924, as well as support for child health and experimental surgery.

Currie worked closely with the Dean of Medicine, Charles Martin, in coordinating the Rockefeller-McGill plans. Fedunkiw logically views the largest Rockefeller grant to McGill in April I932 for its Montreal Neurological Institute (MNI) as a continuing extension of the program initiated in 1920 . Currie supervised the planning, siting and close budget control of Penfield's MNI. Fedunkiw comments that Currie "did not live to see the MNI built." But in fact, on McGill's Founder's Day, 6 October 1933, Sir Arthur carried out a grand military style operation for laying the cornerstone of the MNI, by the Governor General, Lord Bessborough, with many dignitaries in attendance and the Canadian Grenadiers as an honorary guard. A large gap in the front façade represented what would become the main entrance, but the structure already reached up 9 stories. The institute would be officially opened in September 1934 by the Director, Wilder Penfield, and his staff, amidst much academic fanfare.

Penfield, as a Rhodes scholar at Oxford in I9I5, captivated by Osler's charm and erudition, took him as his life-long medical hero. Thus, it marked an apt historical sequence to have the MNI as the crowning feature of the Rockefeller program that was triggered by Osler's note of I9I9, to bring about this great experiment "in promoting medical education in Canada."

\section{William Feindel}

Director Emeritus

Montreal Neurological Institute Montréal, Que.

Honorary Osler Librarian

\section{One thousand words}

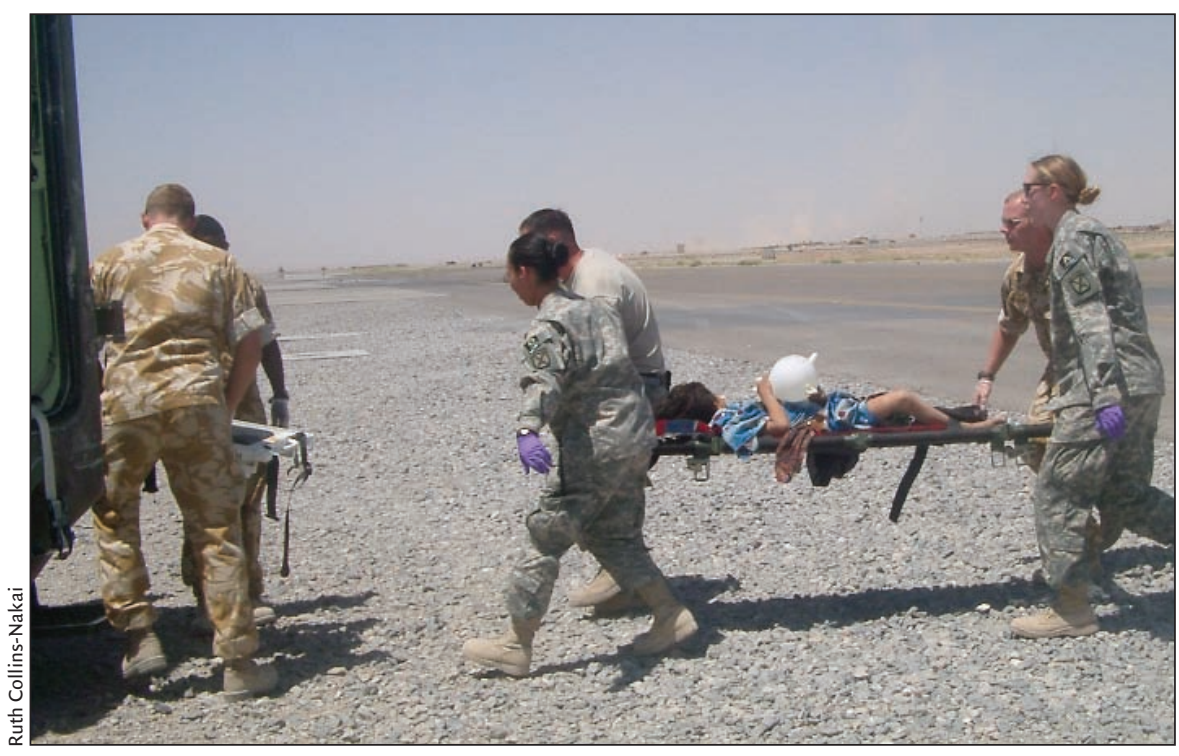

Kandahar Airfield, Afghanistan, 2006: No words, even a thousand, can describe the reality of a child wounded in a war zone. A photo can only give us a glimpse. Here an injured child clutches a surgical glove made into a balloon and painted with a clown's face. She is "caught in the crossfire," "a civilian casualty" in reports in Canada; she is a haunting reality to the physicians who treat her. When not treating armed forces members, much of the current work of military physicians on deployment is in treating civilians. This includes working in villages and the countryside, where access to advanced medical care is otherwise non-existent. - Cathy Younger-Lewis, CMAJ 